NBER WORKING PAPER SERIES

\title{
THE ECONOMIC COST OF HARBORING TERRORISM
}

\author{
Efraim Benmelech \\ Claude Berrebi \\ Esteban F. Klor \\ Working Paper 15465 \\ http://www.nber.org/papers/w15465
NATIONAL BUREAU OF ECONOMIC RESEARCH
1050 Massachusetts Avenue
Cambridge, MA 02138 \\ October 2009
}

We are grateful to Daniele Paserman, Todd Sandler, two anonymous referees, and participants of the 2009 Conference on Terrorism and Policy at the University of Texas at Dallas and the 2009 meeting of the Network for the Economic Analysis of Terrorism (NEAT) in Brussels for very helpful suggestions. We thank the Israeli Security Agency for providing us with their data on suicide terrorists, and the Palestinian Central Bureau of Statistics for the data from the Labor Force Survey. Benmelech thanks the Warburg Fund at Harvard University for financial support. Berrebi and Klor are grateful for the support from the "New Agenda for European Security Economics (EUSECON)" project funded by the European Commission under the 7th Framework Programme. Klor thanks the warm hospitality of Boston University and the National Bureau of Economic Research while he was working on this project. This document has not been subject to formal review by the RAND Corporation. The opinions and conclusions are solely those of the authors and do not necessarily represent the opinions or policy of the RAND Corporation, nor of its research clients and sponsors, nor of the National Bureau of Economic Research.

NBER working papers are circulated for discussion and comment purposes. They have not been peerreviewed or been subject to the review by the NBER Board of Directors that accompanies official NBER publications.

(C) 2009 by Efraim Benmelech, Claude Berrebi, and Esteban F. Klor. All rights reserved. Short sections of text, not to exceed two paragraphs, may be quoted without explicit permission provided that full credit, including $\left({ }^{\circ}\right.$ notice, is given to the source. 
The Economic Cost of Harboring Terrorism

Efraim Benmelech, Claude Berrebi, and Esteban F. Klor

NBER Working Paper No. 15465

October 2009

JEL No. H41,H56,J01,O1,O53

\begin{abstract}
$\underline{\text { ABSTRACT }}$
The literature on conflict and terrorism has paid little attention to the economic costs of terrorism for the perpetrators. This paper aims to fill that gap by examining the economic costs of committing suicide terror attacks. Using data covering the universe of Palestinian suicide terrorists during the second Palestinian uprising, combined with data from the Palestinian Labor Force Survey, we identify and quantify the impact of a successful attack on unemployment and wages. We find robust evidence that terror attacks have important economic costs. The results suggest that a successful attack causes an increase of 5.3 percent in unemployment, increases the likelihood that the district's average wages fall in the quarter following an attack by more than 20 percent, and reduces the number of Palestinians working in Israel by 6.7 percent relative to its mean. Importantly, these effects are persistent and last for at least six months after the attack.
\end{abstract}

Efraim Benmelech

Harvard University

Department of Economics

Littauer 233

Cambridge, MA 02138

and NBER

effi_benmelech@harvard.edu

Claude Berrebi

Rand Corporation

1776 Main Street

P.O. Box 2138

Santa Monica, CA 90407-2138

Claude_Berrebi@rand.org
Esteban F. Klor

Dept. of Economics

Hebrew University

Mount Scopus

Jerusalem ISRAEL 91905

eklor@mscc.huji.ac.il 


\section{Introduction}

One of the main goals of terrorism is to impose economic, psychological, sociological and political costs on the targeted society in order to coerce its government into granting political and territorial concessions. Although the success of terrorists in achieving this goal is still being debated (Gould and Klor, 2009), there is a growing body of empirical work showing that terror campaigns impose important economic costs on the targeted societies. For example, the seminal work of Abadie and Gardeazabal (2003) shows that per capita GDP in the Basque Country is about 10 percentage points lower than it could have been in the absence of terrorism, as a consequence of the outbreak of the conflict in this region in $1960 .{ }^{1}$ Likewise, Eckstein and Tsiddon (2004) and Berrebi and Klor (2009) find that the second Palestinian uprising had an effect of a similar magnitude on the Israeli economy. The effects of terrorism are magnified in small economies like the Basque Country, Israel and Greece (Sandler and Enders, 2008; Krueger 2007). However, they are important in other countries as well, particularly those in the process of development (Gaibulloev and Sandler, 2009). ${ }^{2}$

Most of the literature on the economic consequences of terrorism focuses on the economy of the targeted country. However, terrorism may have also unintended economic consequences on

\footnotetext{
${ }^{1}$ Mickolus et al. (1989) showed that ETA especially targeted hotels and resorts to cause a decline in incoming tourism and hurt the overall Spanish economy. See also Enders and Sandler (1991), who are the first to compute the economic cost of terrorism.

${ }^{2}$ The studies cited above are but just a very small sample of the existent evidence on the effects of terrorism on economic outcomes in a given country. Abadie and Gardeazabal (2008) calculate the effects of terrorism on the entire world economy. See Enders and Sandler (2006) for a more comprehensive discussion of the related literature.
} 
the economy of the society harboring the perpetrators of terror attacks. This is the focus of our study.

Our analysis identifies and quantifies the effect of harboring terrorists on the local economy. In particular, we focus on the Palestinian economy and assess the impact of successful Palestinian suicide attacks against Israeli targets on Palestinian unemployment, wages and access of Palestinian workers to the more lucrative Israeli labor market. Our results show that successful attacks have important economic consequences for the suicide terrorist's district of origin. In particular, a successful attack causes an immediate increase of 5.3 percent in the unemployment rate of an average Palestinian district (relative to the average unemployment rate), and causes an increase of more than 20 percent in the likelihood that the district's average wage falls in the quarter following an attack. Finally, a successful attack reduces the number of Palestinians working in Israel by 6.7 percent relative to its mean. Importantly, these economic effects persist for at least two quarters after the attack.

By measuring the economic costs of terrorism to the harboring society, our study contributes to the literature on the economic costs of conflict. There are two main challenges in identifying the causal effect of terrorism on the harboring society. First, in a large number of conflicts plagued by terrorism, perpetrators and targeted population live side by side, making it difficult to obtain the appropriate data that would allow researchers to disentangle the effect of terrorism on the perpetrators. This is certainly the case in conflicts that attracted a lot of the researchers' attention, like the ones in the Basque Country, Iraq and Afghanistan.

Second, even for those conflicts where the appropriate data are available, solid empirical evidence has yet to be produced. The lack of evidence based on these conflicts is perhaps due to the difficulty involved in identifying the causal effect of terror on economic outcomes. Simply 
put, an extant correlation between terrorism and economic conditions does not necessarily imply that terrorism is costly. Rather, it may be that bad economic conditions are conducive to the launch of a terror campaign. ${ }^{3}$ Alternatively, other factors, like political institutions and religious beliefs, may simultaneously affect economic conditions and the severity of terror (Abadie, 2006; Krueger and Laitin 2008).

Our analysis overcomes these difficulties by relying on a detailed data set of suicide terror attacks and local economic conditions together with a unique empirical strategy. The available data set covers the universe of suicide Palestinian terrorists during the second Palestinian uprising, combined with quarterly data from the Palestinian Labor Force Survey on districts' economic and demographic characteristics, and Israeli security measures (curfews and Israeliinduced Palestinian fatalities). Our empirical strategy exploits the inherit randomness in the success or failure of suicide terror attacks as a source of exogenous variation to investigate the effects of terrorism on the perpetrators economic conditions. ${ }^{4}$ We do so by considering only attacks that were actually initiated (i.e., in which the terrorist was dispatched), and use the exogenous variation in the outcomes of these attacks as our source of identification. We differentiate between two main outcomes: a successfully completed attack (treatment) and

\footnotetext{
${ }^{3}$ There is a large literature that investigates whether or not economic conditions cause terrorism. See Enders and Sandler (2006) and Krueger (2007) for recent comprehensive surveys.

${ }^{4}$ Jones and Olken $(2005,2009)$ use a similar empirical strategy based on the random survival of country leaders. Jones and Olken (2005) examine the effect of a leader's death on a country's economic performance. More related to our study, Jones and Olken (2009) focus on the effect of the successful assassination of a country's leader on that country political institutions and the likelihood of war.
} 
attacks in which the terrorist was "caught" by the Israeli Security Agency (control). ${ }^{5}$ These are all the relevant cases where the success or failure of the attempted suicide attack was most likely not determined by pre-existing economic conditions. Thus, our identification relies on the assumption that, even if the initiation of an attack is endogenously determined by economic conditions, conditional on launching an attack, those conditions do not directly affect the success or failure of the operation. ${ }^{6}$

In addition, our econometric strategy can rule out alternative explanations to the observed economic fluctuations. First, by focusing on one particular conflict, our analysis is not affected by the concerns associated with studies based on cross-countries comparisons. Second, we do not focus on levels, but rather changes of all variables used in the analysis, thus effectively controlling for districts' fixed characteristics that may jointly affect economic conditions and the occurrence of suicide attacks. We also control for changes in districts' demographic characteristics so that our results are not affected by temporary migration of part of the population in the aftermath of a terror attack. Moreover, these economic effects are obtained after controlling for the economic impact of local counter-terrorism measures imposed by the

\footnotetext{
${ }^{5}$ We provide a formal definition of a "caught" suicide terrorist while describing the available data. Basically, a terrorist is classified as caught by the ISA if the terrorist failed to complete the attack as planned because he or she was intercepted by the security services before reaching the intended target.

${ }^{6}$ Economic conditions can indirectly affect the mission's success. For example, Benmelech and Berrebi (2007) show that more educated and older suicide terrorists are less likely to fail or to be caught.
} 
Israeli security forces in the aftermath of an attack. ${ }^{7}$ Therefore, we believe that our analysis provides reliable estimates on the economic costs of harboring terrorism.

The results, therefore, imply that a successful suicide attack has significant economic consequences to the perpetrating society. These economic costs could be due to a number of mechanisms. Terror attacks may have economic consequences due to security measures (which we may not be fully capturing with the available measures) that prevent local residents from continuing to work regularly. It is also possible that even if local workers are not prevented from reaching their place of work, employers in Israel may be reluctant to hire workers from a district that launched an attack. Moreover, other researchers have argued that successful attacks may cause the radicalization of the local population (Jaeger et al. 2008; Bueno de Mesquita and Dickson, 2007). The radicalization of the population, in turn, brings about self-deprivation and the de-prioritization of economic achievement, which translate into lacking economic performances (Hillman, 2007; Berman, 2000).

\section{Data}

\subsection{Suicide Attacks}

Our data set contains detailed information on all suicide attacks by Palestinians against Israeli targets in Israel, the West Bank and the Gaza Strip between September 2000 and December 2006.

This data set is an updated version of the data set constructed by Benmelech and Berrebi (2007) from reports of the Israeli Security Agency (ISA). The Israeli Security Agency reports for

\footnotetext{
${ }^{7}$ Note that none of the available proxies for counter-terrorism measures reflects a particularly targeted policy against the suicide terrorist or his family. Rather, they reflect the use of measures that affect the overall population in the district of origin of the suicide terrorist.
} 
that period cover 159 suicide attacks carried out by 176 suicide terrorists in Israel, the West Bank and Gaza Strip. According to ISA, there were about 30,000 Palestinian attacks against Israeli citizens and residents between September 2000 and December 2006. These attacks caused over 1,000 Israelis fatalities. While suicide attacks account for only 0.5 percent of the total number of attacks, the number of fatalities in suicide attacks represents more than half the number of all Israelis killed in terror attacks during this period. ${ }^{8}$

To construct our data set, we exclude from ISA's reports suicide attacks that were launched by non-Palestinians or in which we could not identify the target or the perpetrator's district of origin. We also exclude attack plots where the terrorists were apprehended at the preparation stages since we cannot be certain that the plot necessarily would have taken the form of a suicide attack. As a consequence, after excluding the cases above, our data set includes 143 suicide attacks carried out by 157 suicide terrorists. This sample represents 90 percent of the total number of suicide attacks between September 2000 and December 2006, and is the universe of Palestinian suicide attacks that caused at least one Israeli civilian fatality. These attacks combined resulted in 597 Israeli fatalities with over 4,040 citizens injured.

Not all suicide terrorists during the period at issue successfully reached their target and completed their mission. In fact, a large number of suicide terrorists in our data set failed in their missions and were caught or intercepted by security forces or civilians during the attack. All these terrorists are clearly identified in the ISA reports. Following these reports, we classify

\footnotetext{
${ }^{8}$ In principle, we would have liked to extend our analysis to all terror attacks. We cannot include non-suicide attacks in our sample for two reasons. First, we do not have information on unsuccessful non-suicide attacks, which in the overwhelming majority of cases were conducted by snipers firing at Israeli targets. Second, even in the cases of successful non-suicide attacks, we do not have information on the perpetrator of the attack, nor on his or her district of residence.
} 
suicide terrorists as "stopped" or "caught" if they: i) failed to detonate their explosive devices, ii) looked suspicious and were apprehended or killed by civilians, policemen or soldiers, before they were able to activate their explosives, iii) panicked and blew themselves up before they reached the target or died during capture, or iv) changed their minds and surrendered to the authorities. Out of the 157 suicide terrorists in our sample, there are 39 failed suicide terrorists: 12 were caught alive and 27 were killed.

The data displays clear differences in lethality between successful suicide terrorist and those that were caught. Whereas successfully completed attacks result on average in about 5 fatalities with 33 individuals injured during the attack, unsuccessful attacks cause on average 0.28 fatalities with 5.23 individuals injured during the attack attempt. ${ }^{9}$

Although there is an obvious correlation between the level of fatalities and whether or not the suicide terrorist was caught, the correlation is not perfect. That is, some "stopped attacks" end-up killing people, while some "successful attackers" do not cause any casualties. For example, on May 19, 2002 the suicide terrorist Osama 'Adel Ahmad Bushkar, a resident of the 'Askar refugee camp near Nablus, was sent by the Palestinian Islamic Jihad (PIJ) terrorist-operative infrastructure in Nablus on a suicide mission to be executed in Israeli territory. ${ }^{10}$ The attack

\footnotetext{
${ }^{9}$ Excluded from these counts are the perpetrators themselves.

${ }^{10}$ In actuality, the attack was carried jointly by the PIJ and the Popular Front for the Liberation of Palestine (PFLP). According to the ISA report regarding this attack, the PIJ operatives behind the attack were in constant communication with the PFLP detainees in Jericho via telephone and courier and updated them regularly about the preparations for the attack. In addition, the driver, 'Adel Mahmoud Juma', a resident of Taybeh, and another escort, Daa' Ziyad Jamil Jayusi, a resident of Tulkarm and student at Al-Najah University, both of whom accompanied Osama
} 
intended to target one of the busiest and most crowded spots within the market of the Israeli coastal city of Netanya. In preparation for the attack, the suicide terrorist obtained IDF uniforms, which he wore as a disguise in the day of the attack in an attempt to inconspicuously access the crowded market. Despite his disguise as an IDF soldier (or maybe because of it) the terrorist aroused the suspicions of a local security patrol, which then approached him for questioning. Realizing that his cover was compromised, the suicide terrorist blew himself up immediately, and thus did not reach the initially intended target. In the process, the suicide terrorist managed to kill three civilians and injure sixty others. Given that the terrorist was not able to reach the intended target, we classify the attack as "stopped by Israeli security," even though the suicide terrorist blew himself up and managed to kill Israeli civilians.

There are opposite cases in our data as well. Namely, that a successful, undetected, and fully completed attack does not cause any casualties beyond the death of the perpetrators. For example, on May 25, 2001 the suicide terrorist Hussein Hassan Abu Nasr, a resident of the Jabaliya refugee camp in the northern Gaza Strip and a student at the Islamic University, drove a tanker that contained three containers of bottled gas in the cabin and $48 \mathrm{~kg}$ (about $106 \mathrm{lbs}$ ) of homemade explosives near the Nezarim junction in the Gaza Strip. ${ }^{11}$ The tanker blew up, according to plan and on location, with the suicide bomber on the driver's seat. This attack is coded as successful in our data since it was fully completed and undetected, despite the fact that the attacker failed to inflict any Israeli fatalities. While illustrative, these two examples are

'Adel Ahmad Bushkar to the attack location, were affiliated with the PFLP. The PFLP ultimately took responsibility for the attack.

${ }^{11}$ Salah Shahadeh, one of Hamas' senior leaders in the Gaza Strip and a founder of Hamas' terrorist-operative wing, planned this attack. 
exceptional. As already stated, the overwhelming majority of successful attacks are also the ones inflicting a large number of casualties, whereas attacks that are eventually stopped tend to cause a relatively lower number of casualties. Thus, while our main empirical specification follows closely the above definition, we also show that using an alternative definition based on the number of casualties caused by each of the attacks does not change any of the results of this paper.

Figure 1 presents a map of Jerusalem, the ten districts of the West Bank, and the five districts of the Gaza Strip. The figure shows, for each district, the total number of suicide terrorists and the total number of suicide terrorists classified as caught. ${ }^{12}$ The figure clearly displays the great variation across districts in terms of their number of suicide terrorists, even within regions. For example, Nablus is the most violent district in the West Bank in terms of harboring terrorists with 43 suicide terrorists. On the contrary, two of its neighboring districts, Salfit and Jericho, did not harbor any suicide terrorist during the time period at issue. A similar pattern is observed in the Gaza Strip, where over 20 suicide terrorists originated from Jabalya and Gaza City, but only 5 from Khan Yunis and Rafah. Overall, during the time period at issue the five districts in the Gaza Strip harbored 34 suicide terrorists, while 122 suicide terrorists came from the ten districts in West Bank and Jerusalem (we do not know the district of origin for one suicide terrorist). Interestingly, despite this large difference in the total number of suicide terrorists harbored by each region, terrorists from both regions have a very similar success rate. Nine suicide terrorists

\footnotetext{
${ }^{12}$ ISA's assignment of a suicide terrorist to a given district is based on the terrorist's last known permanent district of residence, and is not made according to the district where they were born or grew up.
} 
from the Gaza Strip failed in their mission (a failure rate of 0.265), compared to thirty caught suicide terrorists from the West Bank (a failure rate of 0.246).

The data set on suicide terrorists contains additional information on suicide and target characteristics. Out of the 157 suicide terrorists ten were female, ten attacks were carried jointly by two suicide terrorists and two attacks involved three suicide terrorists. Interestingly the number of terrorists involved in an attack did not seem to alter the probability of success. On average, about 25 percent of the suicide attacks failed according to ISA's reports; out of the twelve attacks perpetrated jointly by two or three terrorists, three $(25 \%)$ were classified as failed. ${ }^{13}$ Regarding the method used for the attack, most suicide terrorists in our sample (76 of them) use explosive belts, while other methods such as carrying an explosive bag or using an explosive laden transportation vehicle (e.g. a car, a truck, a bus or a boat) are less common. ${ }^{14}$

\subsection{Economic and Demographic Characteristics of Suicide Terrorists' Districts of Origin}

The data for our three economic outcomes of interest (unemployment rate, average wage and percentage of the district's population working in Israel), as well as all the districts-level demographic characteristics, are obtained from the Palestinian Labor Force Survey (PLFS). This

\footnotetext{
${ }^{13}$ Our econometric specification uses all the available observations, including those with two or three suicide terrorists acting together. Given the dichotomous nature of the main explanatory variable, when an attack included multiple terrorists the regression analysis treats every suicide terrorist as an independent observation. While excluding the observations with two or three suicide terrorists acting together somewhat reduces the precision of the estimates, it does not change any of the results of this article.

${ }^{14}$ Our sample includes 23 suicide terrorists who used an explosive bag and 41 who used different explosive laden transportation vehicles. Less common methods include the use of pipes or the use of scuba divers. For 11 attackers the mode of operation remained unknown or unreported.
} 
survey, conducted by the Palestinian Central Bureau of Statistics, provides quarterly information on a rotating representative sample of about 22,000 individuals living in East Jerusalem, the West Bank and the Gaza Strip.

A clarification is in order regarding wage indicator - our proxy for average wage. Due to privacy concerns, the PLFS does not report the actual wage of individuals. Instead, the survey provides a proxy for the individuals' income by classifying individuals without income with a zero, and sorting the rest of the surveyed individuals in any given quarter according to their income into four bins of roughly equal size. The survey assigns a value of one to the individuals in the first bin, two to individuals in the second bin, and a value of three and four to individuals in the third and fourth bin respectively. For the purposes of the analysis, we compute the weighted-average wage indicator for every district-cell, and assign a value of one to wage indicator growth if the wage indicator in the district is higher than in the previous quarter. Otherwise this variable receives a value of zero.

The top panel of Table 1 presents summary statistics of the economic variables of interest, differentiating between district-quarter cells that originated a suicide attack and the rest. This table exhibits some extent of a patterned difference in terms of the economic indicators for cells that originated a suicide terrorist and the rest. Accordingly, cells that originated a suicide terrorist have a significantly higher unemployment rate and a significantly lower percent of their population employed in Israel. These cells also exhibit lower growth in their wage indicator, though not statistically different from that for the rest of the cells. As we have noted earlier, these differences are not enough to establish causality, since it is possible that bad economic conditions are causing suicide attacks, or that other unobserved districts' characteristics are responsible for the observed differences. 
The middle panel of Table 1 presents summary statistics for the demographic variables used as control variables. This panel shows that the two sets of cells are balanced in terms of these characteristics, except for a higher percent of male population in cells that originated suicide terrorists.

\subsection{Data on Security Measures (Curfews and Israeli Induced Palestinian Fatalities)}

Our analysis includes proxies for security measures that the Israeli security forces may impose on each district at any given time. The available measures are the number of Israeliinduced Palestinian fatalities and the number of days with a curfew, both measured per districtquarter cell. The data on Palestinian fatalities during the second Palestinian uprising come from

B'tselem, an Israeli human rights organization. B'tselem's data (considered accurate, reliable and comprehensive) are widely used in studies focusing on the Israeli-Palestinian conflict (see, for example, Jaeger et al., 2008 and Benmelech et al., 2009). The data provide detailed information on every Palestinian fatality, including the date and location of the incident. The data on curfews was obtained from the United Nation's Office for the Coordination of Humanitarian Affairs (OCHA), the organization that, among other responsibilities, monitors closures and curfews imposed on the Palestinian population. OCHA provided us with their data on total hours under curfew by district-month cell between May 2002 and December 2006.

The bottom panel of Table 1 presents statistics related to the security measures. This table shows that district-quarter cells with a suicide attack are characterized by a significantly higher number of Palestinian fatalities and days with curfews compared to the rest of the cells. In particular, during the quarter where a suicide attack was launched, harboring districts suffer from an average of about eight additional Israeli induced fatalities and ten more days of curfew than district-quarter cells from which no suicide attack originates. 
These differences highlight the importance of the counter-terrorism controls in our regressions. As we have mentioned above, the Israeli military presence in the district in the aftermath of the attack is at least partially responsible for the economic consequences suffered by the harboring district. Perhaps more importantly for identification purposes, counter-terror measures not only affect economic conditions but may also affect the outcome of an initiated attack. Hence, without properly controlling for counter-terrorism we would not be able to exploit the success or failure of an attack as a source of exogenous variation.

\section{Empirical Framework}

The chosen empirical specification focuses on district-quarter cells that initiated a suicide terror attack, and assesses whether the outcome of the attack causes changes in economic conditions in the suicide terrorist's district of origin. Formally, we estimate model (1) below,

$$
\begin{aligned}
\left(\Delta{\text { Economic Conditions })_{i, t}=}\right. & \alpha(\text { Outcome of Attack })_{i,-1}+\beta\left(\Delta{\text { Demographic Variables })_{i, t}}\right. \\
& +\gamma(\Delta \text { Security Measures })_{i, t}+\varepsilon_{i},
\end{aligned}
$$

where ( $\Delta$ Economic Conditions) denotes the change in economic conditions at the district level between the quarter immediately after a suicide attack and the quarter immediately preceding the attack. We focus on three economic variables of interest in those districts from which the suicide terrorist originated: the district's unemployment rate, an indicator for increases in the district's income, and the percent of the district's population employed in Israel. The (Outcome of Attack) is a dichotomous indicator that takes the value of one if the suicide attack was completed without being stopped or caught by the Israeli security services, and zero when the suicide attack failed. Thus, our empirical strategy relies on local average treatment effects to identify the economic effects of terrorism from variation in the success of attacks that were launched from specific 
districts in a particular quarter. Additionally, as a robustness test, we show that the results are not affected when we use the number of casualties from an attack as the explanatory variable of interest representing the attack's level of success.

All the specifications control for the changes, between the quarter after the attack and the quarter before the attack, in district's demographic characteristics and Israeli security measures that vary across districts and time. The demographic characteristics accounted for include average years of education, percentage of population living in a refugee camp, average age, proportion of male in the local population and proportion of married population. In addition, we include a West-Bank dummy to control for regional unobservable characteristics that are constant over time, as well as year fixed effects. ${ }^{15}$ Finally, $\varepsilon_{i}$ is an error term (clustered at the regional level) that captures non-systematic determinants of the district's changes in economic conditions.

In addition to the specification used in model (1), we estimate a similar model but looking at the changes in all variables between their levels two quarters after an attack and their levels the quarter that immediately preceded the attack. This estimation allows us to assess the persistence of the effects of successful terror attacks on the economic variables of interest.

\section{Results}

${ }^{15}$ In general, the demographic characteristics of a district do not show a lot of variation between two consecutive quarters. We control for these characteristics, however, to eliminate the possibility that the results are driven exclusively by the temporary migration of the population across districts. That is, the moderate population (which is also more active economically) may temporarily leave a district right in the aftermath of a suicide attack to avoid the expected Israeli retaliation. By controlling for demographic characteristics of the local population, our results do not include temporary migration as one of the costs of suicide terrorism. 


\subsection{Main Specification}

Tables 2 to 4 depict the results of estimating model (1) for local unemployment rate (Table 2), an indicator of wage growth (Table 3), and the percentage of the local population that works in Israel (Table 4). The results in columns 1 and 2 of Table 2 show that a successful suicide terror attack causes an increase of between 0.52 to 0.66 percentage points in the unemployment rate of an average Palestinian district. The specification in column 3 adds to the baseline model the available security measures, which restrict the sample to the years 2002-2006, the only ones for which these variables are available. This estimation shows an effect of greater magnitude, equal to a 1.4 percentage points increase in unemployment. To gauge the economic magnitude of these coefficients, we divide them by the average unemployment rate in all Palestinian districts. The results of these calculations show that a successful suicide terror attack causes an increase in the unemployment rate of the harboring locality that is between 5.3 percent (column 2) to 14 percent (column 3). Thus, an average locality that harbors a suicide terrorist that succeed in his or her attack, sees its unemployment rate increasing immediately after the attack from 9.4 percentage points to up to almost 11 percentage points based on the estimates of column 3 .

Table 3 presents estimates of the same specifications, focusing on the growth of the districts' wage indicator as the outcome of interest. Similar to Table 2, Table 3 suggests that a successful terror attack causes an increase of over 20 percent in the likelihood that the harboring district's average wage decreases in the quarter following an attack. Finally, Table 4 shows that a successful attack causes a reduction in the number of Palestinians working in Israel in the order of 0.2 to 0.34 percentage points. When divided by the districts' average percent of Palestinians working in Israel, this translates into an increase that is between 5.1 percent (column 3) to 6.67 percent (according to column 2) relative to its mean. 


\subsection{Robustness Tests}

This subsection presents two robustness tests to the main specifications in Tables 2, 3 and 4 . The first robustness test, in Table 5, shows the economic impact of suicide terror attacks using the variation in the number of casualties as our main explanatory variable instead of the dichotomous variation on the success of the attacks. As the table shows, the economic effects of suicide terrorism are statistically significant also for this alternative definition of success and failure of the attacks. According to the results, an additional casualty from a suicide attack is associated with increased district's unemployment, a lower probability that the district's average wage increases in the quarter following an attack, and a reduction in the number of Palestinian from the district of the perpetrator terrorist working in Israel. As expected, the quantitative impact of an additional casualty is lower than the effects found in Tables 2 to 4 based on the dichotomous definition of success. As shown in the specification used in the even columns of the table, this is due mainly to a non-linear effect of casualties on the economic outcome of interest. Simply put, we observe an important economic effect of a suicide attack while comparing successful to unsuccessful attempts to commit a suicide attack, but a negligible impact while comparing, for example, suicide attacks that resulted in fifty casualties (the mean number of casualties in suicide attacks with a positive number of fatalities) to those that caused forty-nine or fifty-one casualties. These effects, however, remain strongly statistically significant once the non linearity in the effect of casualties is accounted for by introducing a quadratic term for the number of casualties.

Table 6 presents our second robustness test. This table analyzes the effect of a successful suicide attack on the average economic outcomes of the region outside of the harboring district. 
Put differently, it analyzes the effect of a successful attack on the region hosting the suicide terrorist, while excluding the economic conditions of the district of origin of the suicide attacker. This table thus further analyzes the possibility that the observed effects spillover to other neighboring districts through, among other factors, the mobility of individuals across districts within their region of residence and counter-terror measures imposed not only at the district level but also the regional level.

The results show that the effects of a successful terror attack on neighboring districts are, in most cases, not statistically different from zero. This lead us to conclude that there are not spillover effects of a successful terror attack to neighboring districts due to the migration of the population or counterterrorism activities. Hence, the results suggest that counter-terror measures are selective and imposed mostly on the district of residence of the suicide terrorist.

\subsection{Persistence of the Effects}

The effects estimated in Tables 2 to 4 show that successful attacks have a significant and important immediate effect on the economic outcomes of interest. In terms of the economic costs of these effects, however, it is crucial to explore whether they are short-lived, or rather persist for a long period of time. Obviously, the longer the effects last, the more important their economic magnitudes. We perform an analysis of the persistence of these effects in Table 7. Basically, this table differentiates all the relevant variables between their levels two quarters after an attack and their levels a quarter immediately preceding the attack. Therefore, if we do not find any statistically significant relationship between a successful suicide attack and the outcome of interest, we should conclude that the effects found in Tables 2 to 4 are short lived and last at 
most for one quarter. On the contrary, if the coefficients in Table 7 are statistically significant, we should conclude that the effects of a successful terror attack last at least half a year.

As Table 7 shows, the effects uncovered in Tables 2 to 4 persist, for the most part, for at least two quarters. For most of the specifications, the effects of a successful suicide attack are still statistically significantly different from zero six months after the attack. Moreover, whereas we observe decays in the magnitudes of the effects on wage growth, the estimates on unemployment rate and percent of the population working in Israel are strikingly constant over time, and show even a slight increase. Hence, successful suicide attacks have long-lasting economic effects that persist at least for six months after the occurrence of the attack.

\section{Concluding Remarks}

This paper estimates the economic cost of harboring terrorism. Using a comprehensive data set of suicide terrorism and economic conditions during the Second Palestinian uprising, combined with a unique empirical strategy exploiting exogenous variation in the success of suicide attacks, we find that successful terror attacks lead to increased local unemployment, and lower average wage with fewer Palestinians working in Israel. These effects are not only of an important economic magnitude, but are also relatively long-lived, persisting for at least six months after the attack.

To the best of our knowledge, the current paper is the first to uncover systematic evidence on the economic cost of harboring terrorism. As such, we document an important part of the terrorism equation: while trying to inflict real economic costs on targeted societies, terror organizations also cause significant economic harm to the population that they claim to represent. These findings are important for a variety of reasons. Beyond their direct interpretation they highlight, for instance, the importance of informing the leaders and the 
general population of areas harboring terrorism about the extent of the associated costs. Perhaps this information would help to dissuade terror organizations' supporters, and strengthen the arguments used by the more moderate voices against terror attacks. While in this study we were able to uncover the costs of harboring terrorism for the average population, an important next step for direct policy recommendations is to disentangle that effect across different subpopulations. That is, it is crucial to better identify the characteristics of the individuals most harmed by harboring terrorism. These individuals should be the first ones mobilized by policy makers trying to create a moderate coalition against terrorism.

Our analysis has also indirect implications regarding foreign monetary aid to areas that harbor terrorism. International groups and organizations often claim that the general civilian population of countries harboring terrorism is nothing but another victim of terrorism. This population, living in poor conditions, often relies on terror organizations for the provision of important public goods. In return, they provide safe havens, support, or at least turn a "blind eye" to terror activities. As the claim goes, promoting education and development in these areas will free the civilian population from their reliance on terror organizations and, over time, cause a decrease in the level of violence. Our results put into question the overall effect of foreign aid. While it is desirable to promote education and development of any population, foreign monetary aid to countries harboring terror organizations mitigates the economic costs of terrorism. As such, it dampens the incentives of the general civilian population to mobilize against terror groups that claim to further their political grievances by means of violent methods. 


\section{References}

Abadie, Alberto. 2006. Poverty, Political freedom and the roots of terrorism. The American Economic Review 96 (2): 50-56.

Abadie, Alberto, and Javier Gardeazabal. 2008. Terrorism and the world economy. European Economic Review 52 (1): 1-27.

Abadie, Alberto, and Javier Gardeazabal. 2003. The economic cost of conflict: A case study of the Basque Country. The American Economic Review 93 (1): 113-132.

Benmelech, Efraim, and Claude Berrebi. 2007. Human capital and the productivity of suicide bombers. Journal of Economic Perspectives 21 (3): 223-238.

Benmelech, Efraim, Claude Berrebi, and Esteban F. Klor. 2009. Economic conditions and the quality of suicide terrorism. Unpublished manuscript, Harvard University.

Berman, Eli. 2000. Sect, subsidy and sacrifice: An economist's view of ultra-orthodox Jews. Quarterly Journal of Economics 115(3): 905-953.

Berrebi, Claude, and Esteban F. Klor. 2009. The impact of terrorism on the defense industry. Economica, forthcoming.

Bueno de Mesquita, Ethan, and Eric S. Dickson. 2007. The propaganda of the deed: Terrorism, counterterrorism, and mobilization. American Journal of Political Science 51 (2): 364-381.

Eckstein, Zvi, and Daniel Tsiddon. 2004. Macroeconomic consequences of terror: Theory and the case of Israel. Journal of Monetary Economics 51 (5): 971-1002.

Enders, Walter, and Todd Sandler. 2006. The political economy of terrorism. Cambridge: Cambridge University Press.

Enders, Walter, and Todd Sandler. 1991. Causality between transnational terrorism and tourism: The case of Spain. Terrorism 14 (1): 49-58. 
Gaibulloev, Khusrav, and Todd Sandler. 2009. The impact of terrorism and conflicts on growth in Asia. Economics and Politics 21 (3): 359-383.

Gould, Eric D., and Esteban F. Klor. 2009. Does terrorism work? Economics of Security, Working Paper 12.

Hillman, Arye L. 2007. Economic and security consequences of supreme values. Public Choice $131(3-4): 259-280$.

Jaeger, David A., Esteban F. Klor, Sami H. Miaari, and M. Daniele Paserman. 2008. The struggle for Palestinians hearts and minds: Violence and public opinion in the Second Intifada. National Bureau of Economic Research Working Paper 13956.

Jones, Benjamin F., and Benjamin A. Olken. 2005. Do leaders matter? National leadership and growth since World War II. The Quarterly Journal of Economics 120(3): 835-864.

Jones, Benjamin F., and Benjamin A. Olken. 2009. Hit or miss? The effect of assassinations on institutional change and war. American Economic Journal: Macroeconomics 1 (2): 55-87.

Krueger, Alan B. 2007. What makes a terrorist: Economics and the roots of terrorism. Princeton, N.J.: Princeton University Press.

Krueger, Alan B., and David D. Laitin. 2008. Kto Kogo?: A cross-country study of the origins and targets of terrorism. In Terrorism, economic development, and political openness, edited by P. Keefer and N. Loayza, 148-173. Cambridge: Cambridge University Press.

Mickolus, Edward F., Todd Sandler, and Jean Marie Murdock. 1989. International terrorism in the 1980s: A chronology of events. Iowa: Iowa State University Press.

Rosendorff, Peter, and Todd Sandler. 2004. Too much of a good thing? The proactive response dilemma. Journal of Conflict Resolution 48(4): 657-671.

Sandler, Todd, and Walter Enders. 2008. Economic consequences of terrorism in developed and 
developing countries: An overview. In Terrorism, economic development, and political openness, edited by P. Keefer and N. Loayza. Cambridge: Cambridge University Press.

Siqueira, Kevin, and Todd Sandler. 2006. Terrorists versus the government: Strategic interaction, support and sponsorship. Journal of Conflict Resolution 50 (6): 878-898. 
Figure 1: Total Number of Suicide Terrorists and Suicide Terrorists Caught by District

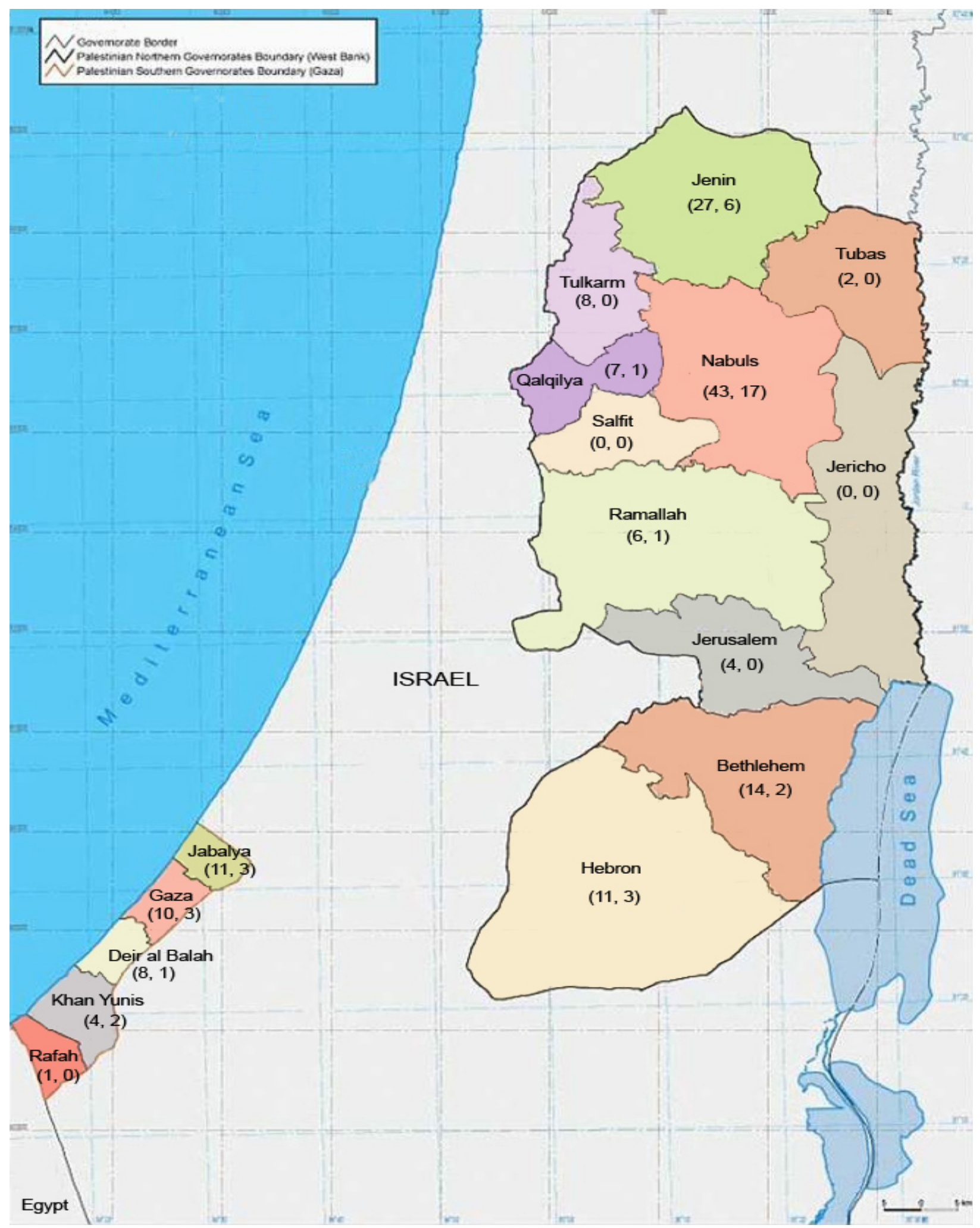


Table 1

Districts Characteristics (Quarterly Averages)

\begin{tabular}{|c|c|c|c|c|}
\hline & All & $\begin{array}{c}\text { Districts-Quarter } \\
\text { Cells without Suicide } \\
\text { Attacks } \\
\end{array}$ & $\begin{array}{c}\text { Districts-Quarter } \\
\text { Cells with Suicide } \\
\text { Attacks } \\
\end{array}$ & $\begin{array}{c}\text { Difference of } \\
\text { Means }\end{array}$ \\
\hline \multicolumn{5}{|l|}{ Economic Variables: } \\
\hline - Unemployment Rate & $\begin{array}{c}0.098 \\
(0.037)\end{array}$ & $\begin{array}{c}0.094 \\
(0.038)\end{array}$ & $\begin{array}{c}0.112 \\
(0.031)\end{array}$ & $\begin{array}{l}-0.018 * * * \\
(0.004)\end{array}$ \\
\hline - Wage Indicator & $\begin{array}{c}2.375 \\
(0.406)\end{array}$ & $\begin{array}{l}2.388 \\
(0.419)\end{array}$ & $\begin{array}{l}2.325 \\
(0.350)\end{array}$ & $\begin{array}{l}0.063 \\
(0.043)\end{array}$ \\
\hline - Increase in Wage Indicator & $\begin{array}{c}0.547 \\
(0.498)\end{array}$ & $\begin{array}{c}0.555 \\
(0.498)\end{array}$ & $\begin{array}{l}0.516 \\
(0.502)\end{array}$ & $\begin{array}{l}0.038 \\
(0.059)\end{array}$ \\
\hline - Percentage Employed in Israel & $\begin{array}{c}0.051 \\
(0.043)\end{array}$ & $\begin{array}{c}0.054 \\
(0.044)\end{array}$ & $\begin{array}{c}0.038 \\
(0.035)\end{array}$ & $\begin{array}{l}0.016^{* * *} \\
(0.004)\end{array}$ \\
\hline \multicolumn{5}{|l|}{ Demographic Variables: } \\
\hline - Years of Schooling & $\begin{array}{c}9.203 \\
(0.513)\end{array}$ & $\begin{array}{c}9.202 \\
(0.540)\end{array}$ & $\begin{array}{l}9.206 \\
(0.396)\end{array}$ & $\begin{array}{l}-0.004 \\
(0.060)\end{array}$ \\
\hline - Refugee Camp & $\begin{array}{c}0.170 \\
(0.178)\end{array}$ & $\begin{array}{c}0.174 \\
(0.183)\end{array}$ & $\begin{array}{c}0.158 \\
(0.158)\end{array}$ & $\begin{array}{l}0.015 \\
(0.021)\end{array}$ \\
\hline - West Bank & $\begin{array}{c}0.688 \\
(0.464)\end{array}$ & $\begin{array}{c}0.678 \\
(0.468)\end{array}$ & $\begin{array}{c}0.725 \\
(0.449)\end{array}$ & $\begin{array}{l}-0.047 \\
(0.053)\end{array}$ \\
\hline - Age & $\begin{array}{l}33.633 \\
(0.968)\end{array}$ & $\begin{array}{l}33.619 \\
(0.963)\end{array}$ & $\begin{array}{l}33.689 \\
(0.992)\end{array}$ & $\begin{array}{l}-0.070 \\
(0.114)\end{array}$ \\
\hline - Male & $\begin{array}{c}0.502 \\
(0.013)\end{array}$ & $\begin{array}{c}0.501 \\
(0.013)\end{array}$ & $\begin{array}{c}0.505 \\
(0.013)\end{array}$ & $\begin{array}{l}-0.004 * * * \\
(0.001)\end{array}$ \\
\hline - Married & $\begin{array}{c}0.572 \\
(0.031)\end{array}$ & $\begin{array}{c}0.572 \\
(0.032)\end{array}$ & $\begin{array}{c}0.571 \\
(0.029)\end{array}$ & $\begin{array}{l}0.0006 \\
(0.0037)\end{array}$ \\
\hline Security Measures: & & & & \\
\hline - Palestinian Fatalities & $\begin{array}{c}8.732 \\
(14.210)\end{array}$ & $\begin{array}{c}7.090 \\
(12.272)\end{array}$ & $\begin{array}{l}15.176 \\
(18.828)\end{array}$ & $\begin{array}{l}-8.086 * * * \\
(1.626)\end{array}$ \\
\hline - Number of Days with Curfews & $\begin{array}{c}3.889 \\
(12.413)\end{array}$ & $\begin{array}{c}1.917 \\
(8.005)\end{array}$ & $\begin{array}{l}12.079 \\
(21.228)\end{array}$ & $\begin{array}{c}-10.162 * * * \\
(2.811)\end{array}$ \\
\hline Number of Observations & 448 & 357 & 91 & \\
\hline
\end{tabular}

Source: Authors' calculations using economic and demographic data from the Palestinian Labor Force Survey, fatality data from B'Tselem, and curfews data from the U.N. office for the coordination of humanitarian affairs.

Notes: Entries in the table represent district-quarter means of the respective variable (standard deviations appear in parentheses). The number of days with curfews is onlyl available from the second quarter of 2002. The number of observations for this variable equals 304 (there are 245 cells without attacks and 59 cells with attacks). ${ }^{* * *}$ indicates difference of means statistically significant at $1 \%$ level. 
Table 2

The Effect of Succesful Suicide Attacks on Local Unemployment of Harboring District

\begin{tabular}{|c|c|c|c|}
\hline \multirow{2}{*}{ Variable } & \\
\hline & (1) & $(2)$ & (3) \\
\hline \multicolumn{4}{|l|}{ Outcome of Suicide Attack } \\
\hline - Suicide Terrorist Succesfully Completes the Attack & $\begin{array}{l}0.0066 * * * \\
{[0.0006]}\end{array}$ & $\begin{array}{l}0.0052 * * * \\
{[0.0008]}\end{array}$ & $\begin{array}{l}0.0140 * * * \\
{[0.0035]}\end{array}$ \\
\hline \multicolumn{4}{|l|}{ Districts' Demographic Characteristics } \\
\hline - Years of Schooling & & $\begin{array}{l}-0.0116 * * * \\
{[0.0015]}\end{array}$ & $\begin{array}{c}-0.0097 \\
{[0.0149]}\end{array}$ \\
\hline - Age & & $\begin{array}{l}-0.0050 * * * \\
{[0.0007]}\end{array}$ & $\begin{array}{l}-0.0018 \\
{[0.0029]}\end{array}$ \\
\hline - Married & & $\begin{array}{l}-0.1859 * * * \\
{[0.0228]}\end{array}$ & $\begin{array}{c}-0.2050 * * * \\
{[0.0405]}\end{array}$ \\
\hline - Male & & $\begin{array}{l}-0.1936 * * * \\
{[0.0547]}\end{array}$ & $\begin{array}{c}-0.1873 * * * \\
{[0.0572]}\end{array}$ \\
\hline - Percentage of Population in Refugee Camp & & $\begin{array}{l}0.0562 * * * \\
{[0.0163]}\end{array}$ & $\begin{array}{c}-0.0431 * * * \\
{[0.0076]}\end{array}$ \\
\hline - West Bank & & $\begin{array}{l}0.0009 \\
{[0.0008]}\end{array}$ & $\begin{array}{c}-0.0013 * * * \\
{[0.0002]}\end{array}$ \\
\hline \multicolumn{4}{|l|}{ Security Related Variables } \\
\hline - Palestinian Fatalities & & & $\begin{array}{c}-0.00001 \\
{[0.0002]}\end{array}$ \\
\hline - Days with Curfews & & & $\begin{array}{c}0.00001 \\
{[0.0001]}\end{array}$ \\
\hline Number of Observations & 154 & 154 & 77 \\
\hline$R^{2}$ & 0.179 & 0.256 & 0.404 \\
\hline
\end{tabular}

Source: Authors' calculations using economic and demographic data from the Palestinian Labor Force Survey, suicide attack data from the Israeli Security Agency, fatality data from B'Tselem, and curfews data from the U.N. office for the coordination of humanitarian affairs.

Note: Estimated via OLS. Dependent variable is district i's difference in unemployment rate between quarters $\mathrm{t}+1$ and $\mathrm{t}-1$ where suicide attack occurred in quarter $t$. Similar differences are used for all demographic characteristics and security related variables included in the regressions, except for the West Bank dummy. All regressions include year fixed effects. Robust standard errors, adjusted for clustering at the area level, in brackets; * indicates statistically significant at $10 \%$ level, ** indicates statistically significant at $5 \%$ level: *** indicates statisticallv significant at $1 \%$ level. 
Table 3

The Effect of Succesful Suicide Attacks on District's Wage

\begin{tabular}{|c|c|c|c|}
\hline Variable & $(1)$ & $(2)$ & (3) \\
\hline \multicolumn{4}{|l|}{ Outcome of Suicide Attack } \\
\hline - Suicide Terrorist Succesfully Completes the Attack & $\begin{array}{l}-0.1799 * * * \\
{[0.0414]}\end{array}$ & $\begin{array}{l}-0.2163 * * * \\
{[0.0616]}\end{array}$ & $\begin{array}{l}-0.2410 * * * \\
{[0.0112]}\end{array}$ \\
\hline \multicolumn{4}{|l|}{ Districts' Demographic Characteristics } \\
\hline - Years of Schooling & & $\begin{array}{c}-0.4912 \quad * * * \\
{[0.0600]}\end{array}$ & $\begin{array}{l}0.2912 * * * \\
{[0.0128]}\end{array}$ \\
\hline - Age & & $\begin{array}{l}0.0292 * * * \\
{[0.0095]}\end{array}$ & $\begin{array}{l}0.2505 * * * \\
{[0.0407]}\end{array}$ \\
\hline - Married & & $\begin{array}{l}-4.87444^{* * *} \\
{[0.7215]}\end{array}$ & $\begin{array}{l}-3.5325 * * * \\
{[1.1823]}\end{array}$ \\
\hline - Male & & $\begin{array}{l}13.3293 * * * \\
{[0.0207]}\end{array}$ & $\begin{array}{l}5.5255 \\
{[3.7713]}\end{array}$ \\
\hline - Percentage of Population in Refugee Camp & & $\begin{array}{l}0.7922 * * \\
{[0.3435]}\end{array}$ & $\begin{array}{l}-2.4935 * * * \\
{[0.7686]}\end{array}$ \\
\hline - West Bank & & $\begin{array}{l}0.1104 * * * \\
{[0.0045]}\end{array}$ & $\begin{array}{l}0.0303 \\
{[0.0405]}\end{array}$ \\
\hline \multicolumn{4}{|l|}{ Security Related Variables } \\
\hline - Palestinian Fatalities & & & $\begin{array}{l}0.00784 * * * \\
{[0.00303]}\end{array}$ \\
\hline - Days with Curfews & & & $\begin{array}{l}-0.00091 \\
{[0.00145]}\end{array}$ \\
\hline Number of Observations & 154 & 154 & 77 \\
\hline
\end{tabular}

Source: Authors' calculations using economic and demographic data from the Palestinian Labor Force Survey, suicide attack data from the Israeli Security Agency, fatality data from B'Tselem, and curfews data from the U.N. office for the coordination of humanitarian affairs.

Note: The coefficients above represent marginal effects of regressions estimated via Probit. Dependent variable is an indicator of average wage increase in district $i$ between quarters $\mathrm{t}+1$ and $\mathrm{t}-1$ where suicide attack occurred in quarter $\mathrm{t}$. Similar differences are used for all demographic characteristics and security related variables included in the regressions, except for the West Bank dummy. All regressions include year fixed effects. Robust standard errors, adjusted for clustering at the area level, in brackets; * indicates statistically significant at $10 \%$ level, ** indicates statistically significant at $5 \%$ level; *** indicates statistically significant at $1 \%$ level. 
Table 4

The Effect of Succesful Suicide Attacks on Percentage of District's Population Working in Israel

\begin{tabular}{|c|c|c|c|}
\hline \multirow[b]{2}{*}{ Variable } & \\
\hline & (1) & (2) & (3) \\
\hline \multicolumn{4}{|l|}{ Outcome of Suicide Attack } \\
\hline - Suicide Terrorist Succesfully Completes the Attack & $\begin{array}{l}-0.0020 \\
{[0.0029]}\end{array}$ & $\begin{array}{c}-0.0034 * * * \\
{[0.0010]}\end{array}$ & $\begin{array}{c}-0.0026 * * * \\
{[0.0003]}\end{array}$ \\
\hline \multicolumn{4}{|l|}{ Districts' Demographic Characteristics } \\
\hline - Years of Schooling & & $\begin{array}{l}-0.0356 * * * \\
{[0.0045]}\end{array}$ & $\begin{array}{l}-0.0110 * * * \\
{[0.0003]}\end{array}$ \\
\hline - Age & & $\begin{array}{c}-0.0094 * * * \\
{[0.0013]}\end{array}$ & $\begin{array}{l}-0.0007 \\
{[0.0010]}\end{array}$ \\
\hline - Married & & $\begin{array}{l}-0.0084 \\
{[0.0336]}\end{array}$ & $\begin{array}{l}-0.0004 \\
{[0.0350]}\end{array}$ \\
\hline - Male & & $\begin{array}{c}-0.0695 * * * \\
{[0.0083]}\end{array}$ & $\begin{array}{l}0.0787 * \\
{[0.0432]}\end{array}$ \\
\hline - Percentage of Population in Refugee Camp & & $\begin{array}{c}-0.0709 * * * \\
{[0.0106]}\end{array}$ & $\begin{array}{c}-0.0173 \\
{[0.0193]}\end{array}$ \\
\hline - West Bank & & $\begin{array}{l}0.0026 * * * \\
{[0.0001]}\end{array}$ & $\begin{array}{c}-0.0007 * * * \\
{[0.0002]}\end{array}$ \\
\hline \multicolumn{4}{|l|}{ Security Related Variables } \\
\hline - Palestinian Fatalities & & & $\begin{array}{r}-0.00006 * \\
{[0.00003]}\end{array}$ \\
\hline - Days with Curfews & & & $\begin{array}{l}0.00009 * * * \\
{[0.00001]}\end{array}$ \\
\hline Number of Observations & 154 & 154 & 77 \\
\hline$R^{2}$ & 0.238 & 0.422 & 0.347 \\
\hline
\end{tabular}

Source: Authors' calculations using economic and demographic data from the Palestinian Labor Force Survey, suicide attack data from the Israeli Security Agency, fatality data from B'Tselem, and curfews data from the U.N. office for the coordination of humanitarian affairs.

Note: Estimated via OLS. Dependent variable is district i's difference in percentage of population working in Israel between quarters $t+1$ and $t-1$ where suicide attack occurred in quarter $t$. Similar differences are used for all demographic characteristics and security related variables included in the regressions, except for the West Bank dummy. All regressions include year fixed effects. Robust standard errors, adjusted for clustering at the area level, in brackets; * indicates statistically significant at $10 \%$ level, ** indicates statistically significant at $5 \%$ level; *** indicates statistically significant at $1 \%$ level. 
Table 5

The Effect of Number of Casualties from Suicide Attacks on District's Economic Outcomes

\begin{tabular}{|c|c|c|c|c|c|c|}
\hline \multirow[b]{2}{*}{ Variable } & \multicolumn{2}{|c|}{ Unemployment } & \multicolumn{2}{|c|}{ Wages } & \multicolumn{2}{|c|}{ Population Working in Israel } \\
\hline & $(1)$ & (2) & (3) & (4) & $(5)$ & $(6)$ \\
\hline \multicolumn{7}{|l|}{ Outcome of Suicide Attack } \\
\hline - Number of casualties from suicide terror attack (in thousands) & $\begin{array}{c}-0.0182 \\
{[0.038]}\end{array}$ & $\begin{array}{l}0.0703 * * * \\
{[0.020]}\end{array}$ & $\begin{array}{l}-0.5262 * * * \\
{[0.070]}\end{array}$ & $\begin{array}{l}-8.3565 * * * \\
{[0.567]}\end{array}$ & $\begin{array}{l}-0.0424 * * * \\
{[0.004]}\end{array}$ & $\begin{array}{l}-0.2048 * * * \\
{[0.035]}\end{array}$ \\
\hline - Number of casualties from suicide terror attack square (in thousands) & & $\begin{array}{l}-0.6718 * * * \\
{[0.138]}\end{array}$ & & $\begin{array}{l}65.1683 * * * \\
{[2.615]}\end{array}$ & & $\begin{array}{l}1.2338 * * * \\
{[0.225]}\end{array}$ \\
\hline \multicolumn{7}{|l|}{ Districts' Demographic Characteristics } \\
\hline - Years of Schooling & $\begin{array}{l}-0.0110 * * * \\
{[0.003]}\end{array}$ & $\begin{array}{l}-0.0112 * * * \\
{[0.003]}\end{array}$ & $\begin{array}{l}-0.4134 * * * \\
{[0.019]}\end{array}$ & $\begin{array}{l}-0.4118 * * * \\
{[0.007]}\end{array}$ & $\begin{array}{l}-0.0342 * * * \\
{[0.003]}\end{array}$ & $\begin{array}{l}-0.0340 * * * \\
{[0.004]}\end{array}$ \\
\hline - Age & $\begin{array}{l}-0.0068 * * * \\
{[0.001]}\end{array}$ & $\begin{array}{l}-0.0069 * * * \\
{[0.002]}\end{array}$ & $\begin{array}{l}0.0138 * * * \\
{[0.003]}\end{array}$ & $\begin{array}{l}0.0265 * * * \\
{[0.006]}\end{array}$ & $\begin{array}{l}-0.0099 * * * \\
{[0.000]}\end{array}$ & $\begin{array}{l}-0.0098 * * * \\
{[0.001]}\end{array}$ \\
\hline - Married & $\begin{array}{l}-0.2004 * * * \\
{[0.016]}\end{array}$ & $\begin{array}{l}-0.2114 * * * \\
{[0.019]}\end{array}$ & $\begin{array}{l}-5.0925 * * * \\
{[0.829]}\end{array}$ & $\begin{array}{l}-4.7384 * * * \\
{[1.216]}\end{array}$ & $\begin{array}{c}-0.0186 \\
{[0.024]}\end{array}$ & $\begin{array}{l}0.0016 \\
{[0.038]}\end{array}$ \\
\hline - Male & $\begin{array}{l}-0.1817 * * * \\
{[0.021]}\end{array}$ & $\begin{array}{l}-0.1774 * * * \\
{[0.021]}\end{array}$ & $\begin{array}{l}13.6071 * * * \\
{[0.099]}\end{array}$ & $\begin{array}{l}14.1193 * * * \\
{[0.062]}\end{array}$ & $\begin{array}{l}-0.0560 * * * \\
{[0.017]}\end{array}$ & $\begin{array}{l}-0.0638 * * * \\
{[0.015]}\end{array}$ \\
\hline - Percentage of Population in Refugee Camp & $\begin{array}{r}-0.0086 \\
{[0.117]}\end{array}$ & $\begin{array}{c}-0.0086 \\
{[0.117]}\end{array}$ & $\begin{array}{c}-0.1038 \\
{[0.130]}\end{array}$ & $\begin{array}{l}0.0781 * * * \\
{[0.022]}\end{array}$ & $\begin{array}{l}-0.0974 * * * \\
{[0.028]}\end{array}$ & $\begin{array}{l}-0.0974 * * * \\
{[0.027]}\end{array}$ \\
\hline - West Bank & $\begin{array}{l}-0.0016 * * * \\
{[0.001]}\end{array}$ & $\begin{array}{c}-0.0008 \\
{[0.001]}\end{array}$ & $\begin{array}{l}0.0732 * * * \\
{[0.000]}\end{array}$ & $\begin{array}{l}0.0113 * * * \\
{[0.001]}\end{array}$ & $\begin{array}{c}0.0004 \\
{[0.001]}\end{array}$ & $\begin{array}{c}-0.0010 \\
{[0.001]}\end{array}$ \\
\hline \multicolumn{7}{|l|}{ Security Related Variables } \\
\hline - Palestinian Fatalities & $\begin{array}{l}0.0003 \\
{[0.000]}\end{array}$ & $\begin{array}{l}0.0003 \\
{[0.000]}\end{array}$ & $\begin{array}{l}0.0039 * * * \\
{[0.001]}\end{array}$ & $\begin{array}{c}0.0033 \\
{[0.002]}\end{array}$ & $\begin{array}{l}0.0001 \\
{[0.000]}\end{array} *$ & $\begin{array}{l}0.0001 \\
{[0.000]}\end{array}$ \\
\hline Number of Observations & 154 & 154 & 154 & 154 & 154 & 154 \\
\hline$R^{2}$ & 0.293 & 0.296 & 0.215 & 0.241 & 0.436 & 0.450 \\
\hline
\end{tabular}

Source: Authors' calculations using economic and demographic data from the Palestinian Labor Force Survey, suicide attack data from the Israeli Security Agency, fatality data from B'Tselem, and curfews data from the U.N. office for the coordination of humanitarian affairs.

Note: Estimated via OLS. Dependent variable is district i's difference in economic outcome of interest between quarters $\mathrm{t}+1$ and $\mathrm{t}-1$ where suicide attack occurred in quarter $\mathrm{t}$. Similar differences are used for all demographic characteristics and security related variables included in the regressions, except for the West Bank dummy. All regressions include year fixed effects. Robust standard errors, adjusted for clustering at the area level, in brackets; * indicates statistically significant at $10 \%$ level, $* *$ indicates statistically significant at $5 \%$ level; *** indicates statistically significant at $1 \%$ level. 
Table 6

The Effect of Succesful Suicide Attacks on Economic Conditions of Other Districts in Same Region

\begin{tabular}{|c|c|c|c|c|c|c|c|c|c|}
\hline \multirow[b]{2}{*}{ Variable } & \multicolumn{3}{|c|}{ Unemployment } & \multicolumn{3}{|c|}{ Wage Increases } & \multicolumn{3}{|c|}{ Work in Israel } \\
\hline & $(1)$ & (2) & (3) & (4) & (5) & (6) & (7) & $(8)$ & (9) \\
\hline \multicolumn{10}{|l|}{ Outcome of Suicide Attack } \\
\hline - Suicide Terrorist Succesfully Completes the Attack & $\begin{array}{r}-0.0056 \\
{[0.0036]}\end{array}$ & $\begin{array}{l}-0.0060 * * * \\
{[0.0017]}\end{array}$ & $\begin{array}{l}0.0020 \\
{[0.0064]}\end{array}$ & $\begin{array}{r}-0.2089 \\
{[0.1993]}\end{array}$ & $\begin{array}{l}-0.3606 * * * \\
{[0.1180]}\end{array}$ & $\begin{array}{l}-0.0645 \\
{[0.1908]}\end{array}$ & $\begin{array}{r}-0.0017 \\
{[0.0034]}\end{array}$ & $\begin{array}{l}-0.0016 \\
{[0.0018]}\end{array}$ & $\begin{array}{l}-0.0002 \\
{[0.0003]}\end{array}$ \\
\hline \multicolumn{10}{|l|}{ Districts' Demographic Characteristics } \\
\hline - Years of Schooling & & $\begin{array}{l}0.0509 * * * \\
{[0.0144]}\end{array}$ & $\begin{array}{l}0.0390 * * * \\
{[0.0061]}\end{array}$ & & $\begin{array}{l}2.7634 \\
{[2.8327]}\end{array}$ & $\begin{array}{l}4.5008 \\
{[4.8616]}\end{array}$ & & $\begin{array}{l}-0.0610 * * * \\
{[0.0046]}\end{array}$ & $\begin{array}{l}-0.0115 * * * \\
{[0.0014]}\end{array}$ \\
\hline - Age & & $\begin{array}{l}-0.0282 * * * \\
{[0.0010]}\end{array}$ & $\begin{array}{c}-0.0101 \\
{[0.0158]}\end{array}$ & & $\begin{array}{l}-0.8780 * * \\
{[0.3771]}\end{array}$ & $\begin{array}{l}-1.5990 * * \\
{[0.7013]}\end{array}$ & & $\begin{array}{l}0.0030 \\
{[0.0204]}\end{array}$ & $\begin{array}{l}0.0090 \text { *** } \\
{[0.0003]}\end{array}$ \\
\hline - Married & & $\begin{array}{l}-0.4494 \\
{[0.3465]}\end{array}$ & $\begin{array}{l}0.2017 \\
{[0.1475]}\end{array}$ & & $\begin{array}{c}-28.7111 * * * \\
{[10.3943]}\end{array}$ & $\begin{array}{c}-53.515 * \\
{[32.49]}\end{array}$ & & $\begin{array}{l}-0.2226 \\
{[0.1611]}\end{array}$ & $\begin{array}{l}-0.0916 \\
{[0.1000]}\end{array}$ \\
\hline - Male & & $\begin{array}{c}-0.3229 * \\
{[0.1889]}\end{array}$ & $\begin{array}{c}-1.9208 * \\
{[1.0851]}\end{array}$ & & $\begin{array}{c}36.9373 * * * \\
{[3.7723]}\end{array}$ & $\begin{array}{l}70.957 * \\
{[39.09]}\end{array}$ & & $\begin{array}{l}0.4198 \\
{[0.4896]}\end{array}$ & $\begin{array}{l}0.3724 * \\
{[0.2050]}\end{array}$ \\
\hline - Percentage of Population in Refugee Camp & & $\begin{array}{l}0.0999 \\
{[0.0626]}\end{array}$ & $\begin{array}{c}-0.3614 \\
{[0.3264]}\end{array}$ & & $\begin{array}{l}-4.3591 * * * \\
{[0.3585]}\end{array}$ & $\begin{array}{c}-111.320 * * * \\
{[10.86]}\end{array}$ & & $\begin{array}{l}-0.1271 \\
{[0.1096]}\end{array}$ & $\begin{array}{c}-0.1766 * * * \\
{[0.0205]}\end{array}$ \\
\hline - West Bank & & $\begin{array}{l}0.0065 * * * \\
{[0.0001]}\end{array}$ & $\begin{array}{l}0.0094 * * * \\
{[0.0017]}\end{array}$ & & $\begin{array}{l}-0.6202 * * \\
{[0.2728]}\end{array}$ & $\begin{array}{l}-1.9625 * * \\
{[0.9002]}\end{array}$ & & $\begin{array}{l}-0.0014 * * * \\
{[0.0004]}\end{array}$ & $\begin{array}{l}0.0022 * * * \\
{[0.0001]}\end{array}$ \\
\hline \multicolumn{10}{|l|}{ Security Related Variables } \\
\hline - Palestinian Fatalities & & & $\begin{array}{l}0.00106 * * * \\
{[0.0004]}\end{array}$ & & & $\begin{array}{l}0.19689 * * * \\
{[0.0597]}\end{array}$ & & & $\begin{array}{l}0.00004 \\
{[0.00004]}\end{array}$ \\
\hline - Days with Curfews & & & $\begin{array}{r}-0.00010 \\
{[0.0014]}\end{array}$ & & & $\begin{array}{c}-0.06625 * * * \\
{[0.0063]}\end{array}$ & & & $\begin{array}{c}-0.00012 * * * \\
{[0.00004]}\end{array}$ \\
\hline Number of Observations & 154 & 154 & 77 & 154 & 154 & 77 & 154 & 154 & 77 \\
\hline$R^{2}$ & 0.217 & 0.426 & 0.455 & 0.085 & 0.574 & 0.167 & 0.248 & 0.495 & 0.684 \\
\hline
\end{tabular}

Source: Authors' calculations using economic and demographic data from the Palestinian Labor Force Survey, suicide attack data from the Israeli Security Agency, fatality data from B'Tselem, and curfews data from the U.N. office for the coordination of humanitarian affairs.

Note: Panels A and C estimated via OLS; panel B estimated via probit. Dependent variable is the average change of economic variable of interest between quarters t+1 and t-1 for other districts in region of origin of suicide attack that occurred in quarter t. Similar differences are used for all demographic characteristics and security related variables included in the regressions, except for the West Bank dummy. All regressions include year fixed effects. Robust standard errors, adjusted for clustering at the area level, in brackets; * indicates statistically significant at $10 \%$ level, $* *$ indicates statistically significant at $5 \%$ level; *** indicates statistically significant at $1 \%$ level. 
Table 7

Persistence of the Effect of Succesful Suicide Attacks on Economic Conditions

\begin{tabular}{|c|c|c|c|c|c|c|c|c|c|}
\hline \multirow[b]{2}{*}{ Variable } & \multicolumn{3}{|c|}{ Unemployment } & \multicolumn{3}{|c|}{ Wage Increases } & \multicolumn{3}{|c|}{ Work in Israel } \\
\hline & $(1)$ & $(2)$ & (3) & $(4)$ & (5) & (6) & $(7)$ & $(8)$ & (9) \\
\hline \multicolumn{10}{|l|}{ Outcome of Suicide Attack } \\
\hline - Suicide Terrorist Succesfully Completes the Attack & $\begin{array}{r}0.0136 \\
{[0.0103]}\end{array}$ & $\begin{array}{l}0.0128 * * * \\
{[0.0010]}\end{array}$ & $\begin{array}{l}0.0164 * * * \\
{[0.0007]}\end{array}$ & $\begin{array}{c}-0.1622 \\
{[0.1851]}\end{array}$ & $\begin{array}{l}-0.1681 \\
{[0.1180]}\end{array}$ & $\begin{array}{l}-0.0526 * * * \\
{[0.0086]}\end{array}$ & $\begin{array}{l}-0.0030 * * * \\
{[0.0011]}\end{array}$ & $\begin{array}{l}-0.0040 * * * \\
{[0.0012]}\end{array}$ & $\begin{array}{l}-0.0018 \\
{[0.0023]}\end{array}$ \\
\hline \multicolumn{10}{|l|}{ Districts' Demographic Characteristics } \\
\hline - Years of Schooling & & $\begin{array}{c}-0.0196 * * \\
{[0.0096]}\end{array}$ & $\begin{array}{c}-0.0031 \\
{[0.0023]}\end{array}$ & & $\begin{array}{l}-0.1265 \\
{[0.3418]}\end{array}$ & $\begin{array}{l}-0.2453 * * * \\
{[0.0079]}\end{array}$ & & $\begin{array}{l}-0.0109 * * * \\
{[0.0025]}\end{array}$ & $\begin{array}{l}-0.0005 * * * \\
{[0.0000]}\end{array}$ \\
\hline - Age & & $\begin{array}{l}-0.0112 * * * \\
{[0.0032]}\end{array}$ & $\begin{array}{l}-0.0020 \\
{[0.0027]}\end{array}$ & & $\begin{array}{l}0.0707 \\
{[0.1570]}\end{array}$ & $\begin{array}{c}0.1056 \\
{[0.2310]}\end{array}$ & & $\begin{array}{c}-0.0021 * * \\
{[0.0010]}\end{array}$ & $\begin{array}{c}-0.0006 * \\
{[0.0003]}\end{array}$ \\
\hline - Married & & $\begin{array}{l}-0.0811 \\
{[0.0937]}\end{array}$ & $\begin{array}{c}-0.2547 * * * \\
{[0.0614]}\end{array}$ & & $\begin{array}{l}2.14666^{* * *} \\
{[0.3285]}\end{array}$ & $\begin{array}{l}-3.5848 * \\
{[1.8669]}\end{array}$ & & $\begin{array}{l}0.1266 * * * \\
{[0.0367]}\end{array}$ & $\begin{array}{l}-0.0672 \\
{[0.0875]}\end{array}$ \\
\hline - Male & & $\begin{array}{l}-0.0415 \\
{[0.0288]}\end{array}$ & $\begin{array}{l}-0.2165 \\
{[0.1781]}\end{array}$ & & $\begin{array}{l}7.5840 * * \\
{[3.5621]}\end{array}$ & $\begin{array}{l}-6.2229 * * * \\
{[2.2094]}\end{array}$ & & $\begin{array}{l}0.1001 * * * \\
{[0.0290]}\end{array}$ & $\begin{array}{l}0.0606 * \\
{[0.0357]}\end{array}$ \\
\hline - Percentage of Population in Refugee Camp & & $\begin{array}{c}-0.1501 * \\
{[0.0821]}\end{array}$ & $\begin{array}{c}-0.1827 * * * \\
{[0.0324]}\end{array}$ & & $\begin{array}{l}0.2427 \\
{[1.0685]}\end{array}$ & $\begin{array}{l}-2.9999 * * * \\
{[1.2207]}\end{array}$ & & $\begin{array}{l}0.0148 \\
{[0.0227]}\end{array}$ & $\begin{array}{l}0.0357 \\
{[0.0490]}\end{array}$ \\
\hline - West Bank & & $\begin{array}{l}-0.0015 \\
{[0.0031]}\end{array}$ & $\begin{array}{l}0.0024 \\
{[0.0050]}\end{array}$ & & $\begin{array}{l}0.0371 \\
{[0.0336]}\end{array}$ & $\begin{array}{l}-0.4205 * * * \\
{[0.1293]}\end{array}$ & & $\begin{array}{l}0.0061 * * * \\
{[0.0004]}\end{array}$ & $\begin{array}{l}-0.0031 \\
{[0.0033]}\end{array}$ \\
\hline \multicolumn{10}{|l|}{ Security Related Variables } \\
\hline - Palestinian Fatalities & & & $\begin{array}{l}0.00010 \\
{[0.00017]}\end{array}$ & & & $\begin{array}{l}0.00831 * \\
{[0.00427]}\end{array}$ & & & $\begin{array}{l}-0.00001 \\
{[0.00012]}\end{array}$ \\
\hline - Days with Curfews & & & $\begin{array}{l}0.00014 \\
{[0.00010]}\end{array}$ & & & $\begin{array}{l}-0.00183 \\
{[0.00269]}\end{array}$ & & & $\begin{array}{l}0.00000 \\
{[0.00004]}\end{array}$ \\
\hline Number of Observations & 154 & 154 & 77 & 156 & 154 & 77 & 154 & 154 & 77 \\
\hline$R^{2}$ & 0.189 & 0.309 & 0.480 & 0.078 & 0.127 & 0.167 & 0.160 & 0.267 & 0.159 \\
\hline
\end{tabular}

Source: Authors' calculations using economic and demographic data from the Palestinian Labor Force Survey, suicide attack data from the Israeli Security Agency, fatality data from B'Tselem, and curfews data from the U.N. office for the coordination of humanitarian affairs.

Note: Panels A and C estimated via OLS; panel B estimated via probit. Dependent variable is change of economic variable of interest in district i's between quarters t +2 and t- 1 where suicide attack occurred in quarter t. Similar differences are used for all demographic characteristics and security related variables included in the regressions, except for the West Bank dummy. All regressions include year fixed effects. Robust standard errors, adjusted for clustering at the area level, in brackets; * indicates statistically significant at $10 \%$ level, ** indicates statistically significant at $5 \%$ level; *** indicates statistically significant at $1 \%$ level. 